\title{
Norois
}

Environnement, aménagement, société

$224 \mid 2012$

Agriculture paysanne, circuits courts, territoires périurbains

\section{Small-holdings and sustainable family farming in Galicia and Ireland. A comparative case study}

Petites exploitations et agriculture familiale durable: Une étude de cas comparative en Galice et en Irlande

\section{Carlos Ferrás-Sexto and Patrick O'Flanagan}

\section{OpenEdition}

\section{Journals}

Electronic version

URL: http://journals.openedition.org/norois/4281

DOI: 10.4000/norois. 4281

ISBN: 978-2-7535-2157-5

ISSN: $1760-8546$

\section{Publisher}

Presses universitaires de Rennes

\section{Printed version}

Date of publication: 30 September 2012

Number of pages: $61-76$

ISBN: 978-2-7535-2155-1

ISSN: 0029-182X

Electronic reference

Carlos Ferrás-Sexto and Patrick O'Flanagan, «Small-holdings and sustainable family farming in

Galicia and Ireland. A comparative case study », Norois [Online], 224 | 2012, Online since 30 September 2014, connection on 14 November 2019. URL : http://journals.openedition.org/norois/4281 ; DOI : 10.4000 /norois. 4281 


\title{
Small-holdings and Sustainable Family Farming in Galicia and Ireland: A comparative Case Study
}

\author{
Petites exploitations et agriculture familiale durable: \\ une étude de cas comparative en Galice et en Irlande
}

\author{
Carlos Ferrás Sexto ${ }^{\mathrm{a} *}$, Patrick O’Flanagan ${ }^{\mathrm{b}}$
}

\author{
*Auteur correspondant \\ a Geography Department, Universidade de Santiago de Compostela, Praza Universidade 1. 15782, Santiago de \\ Compostela (Spain) (carlos.ferras@usc.es) \\ b Geography Department, University College Cork. Ireland (p.oflanagan@ucc.ie)
}

\begin{abstract}
Small-holdings and Minifundios were considered as miniature farms, unable to secure basic sustenance for all the members of the family unit and, ultimately, a source of many evils. This research consists of theoretical and empirical sections. The theoretical part focuses on the analysis of specialized bibliography on minifundismo and family farming. We try to present the theoretical background that allows us to provide new ideas about minifundios and family farms. The empirical part focuses on examining different cases in Galicia and Ireland. We attempt to produce a brief comparative diagnosis of the changes and continuities that cooperative family farming has experienced considering that farm censuses statistics systematically ignore the social and cultural contexts of families that live and work on farms. Our intention is to stress the idea that family farming in Galicia and Ireland is a cultural expression and a life-style that goes beyond capitalist industrial farming. It is a type of farming in itself that has both negative and also positive characteristics.
\end{abstract}

Résumé : Les très petites exploitations agricoles en minifundium ou microfundium, ont été considérées par le passé comme des exploitations incapables d'assurer la subsistance de base pour tous les membres de la cellule familiale, inadaptées anjourd'hui à la modernité, et finalement sources de nombreux maux. Cet article a pour intention de démontrer que l'agriculture familiale de Galice et d'Irlande, est une expression culturelle, qu'elle est un véritable style de vie, dont la question va bien au-delà de celle de l'intégration à l'agriculture capitaliste industrielle. Il s'agit d'un type d'agriculture en soi, qui a des caractéristiques propres aussi bien négatives que positives. Une première partie théorique se concentre sur l'analyse de la bibliographie spécialisée sur les micro-exploitations. Ce contexte théorique nous permet de proposer de nouvelles idées sur les micro-exploitations et les fermes familiales. La seconde partie, fondée sur des observations empiriques, porte sur différents cas en Galice et en Irlande. Notre diagnostic comparatif des changements et des continuités que l'agriculture familiale coopérative a connu, tient compte du fait que les statistiques des recensements agricoles ignorent systématiquement les contextes sociaux et culturels des familles qui vivent et travaillent dans ces fermes.

Keywords: family farming - minifundismo - sustainable farming - life-style - rural change.

Mots clés : agriculture familiale - minifundium - agriculture durable - style de vie - campagne. 


\section{INTRODUCTION}

This paper presents the results of an economic, social and cultural study relating to family farms in two cooperatives: Feiraco in Galicia, Spain and Drinagh, County Cork in Ireland. The research is focused mainly on the production and analysis of the results of a specialized survey that dealt with the social, economic, technological and cultural characteristics of dairy farms located in the two cooperatives; one covering several western municipalities of Galicia and the other in West County Cork in Ireland (figure 1). We attempt to produce a brief comparative diagnosis of the changes and continuities cooperative family farming has experienced given that farm censuses statistics systematically ignore the social and cultural contexts of families that live and work on the land. Our intention is to stress the idea that family farming in Galicia is a cultural expression and a life-style that goes beyond capitalist industrial farming. It is a type of farming that has both negative and positive characteristics. Social change and processes of agricultural transformation are clearly evident in the hinterlands of the cooperatives. In the case of Feiraco Cooperative, with its milk-shed located mainly in the municipalities of A Barcala and Negreira, change started with plot consolidation initiated in Galicia at the end of the 1950s. Work mechanization, demographic decline, migratory flows to cities and the improvement of quality of life were dynamic and continuous processes in both cooperatives. However, modern political economy discourses still advocate the adoption of a model of commercial and capitalist agriculture. Perceptions tie existing family farming traditions with cultural, economic and social backwardness. We should really consider in greater depth the advantages of traditional family farming and establish wheather its values are worth supporting. The Irish case is a clear example of a dairy cooperative that lost part of its cultural meaning when most farmers abandoned mixed farming once and for all. Plot consolidation in Ireland was carried out during the first two decades of the twentieth century parallel to a very ambitious re-structuring of settlement and a planned process of establishing isolated farmsteads was favoured (Aalen et al., 2011).

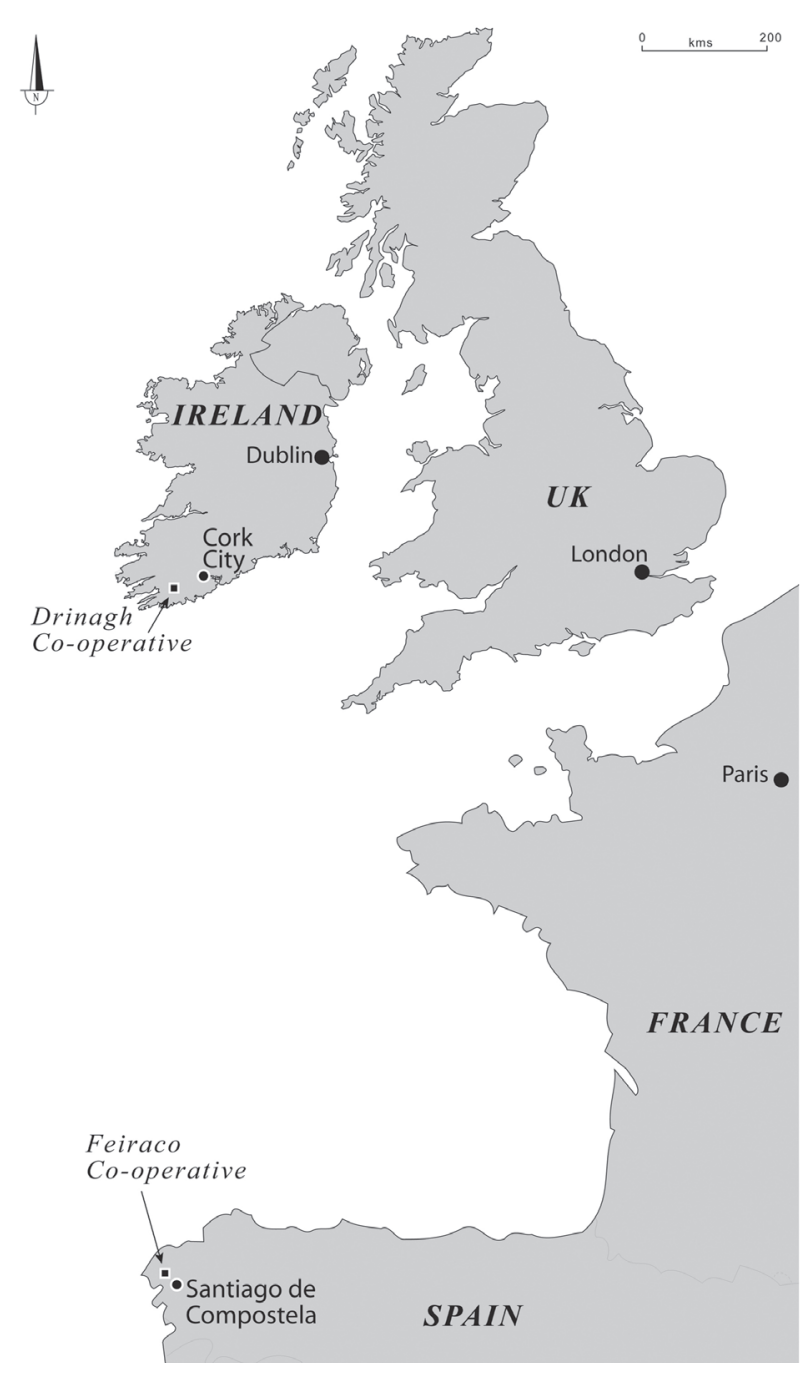

Figure 1: Location of Drinagh and Feiraco (Espagne) Localisation de Drinagh (Irlande) et de Feiraco en Galice

Also, in the Irish case, demographic pressure on the land was remarkably reduced by the mass exodus of rural population to the United States and Britain, due to the potato blight and its impact on food security from the mid 1800s. In West County Cork, the development of capitalist dairy farming was promoted and family farms abandoned their traditional practices in favour of a market approach and increased profits. Ireland's joining the European Economic Community in 1973 was a catalyst to promote modernizing and capitalist family farming practices over the entire island. Spain, delayed membership of the EEC until 1986: this is one of the main reasons that family farming systems have 
survived combining traditional with modern farming, that is, mixed farming or polyculture and selfsufficiency together with industrial dairy farming. Galicia is now going through a period of transition towards industrial agriculture.

Nowadays the defence of capitalist industrial agriculture as modernizing and productive is a discourse in crisis. The industrial production system applied in rural areas gave rise to serious productive inefficiencies, such as the bovine spongiform encephalopathy (mad cow disease). Concepts and their practice such as ecology, life-style, pluriactivities, human-environment equilibrium, sustainability, social and cultural development and post-productive agricultural cooperatives imply new definitions and meaning for the Galician rural world are now being considered (Walshe, 2010).

For the period 2007-2013, the European Commission proposed a reform of the Common Agricultural Policy (CAP) and set as its main objectives the protection and improvement of natural resources, as well as the maintenance of traditional farming and forest systems of great environmental value together with conservation and safeguarding of existing European rural cultural landscapes. In this context, we propose a model of sustainable family farming both environmentally friendly and respectful to inherited farming practices.

The results illustrated by our comparative research should make us reflect about the new Galician rural world, revise pejorative perceptions and instigate new approaches that acknowledge and respect existing culture and life-styles in rural communities. It is necessary to define a "productivity threshold" that enables measures to be taken to preserve, appreciate and value "rural local culture" and, at the same time, guarantee the quality of life for farming families. The Galician rural world cannot move inexorably towards mass plot consolidation or head for exclusive industrial agricultural development. Smallholding cultural practices cannot be replaced by the features of an "invented big-holding system" alien to the social, economic and cultural reality of Galicia. Polyculture on Galician small-holdings is an inherited cultural practice that should be preserved and extended. Polyculture means many different landuses, each one too minute in scale or productive capacity to merit their being classified as separate enterprises. In rural Ireland such inherited cultural practices have all but disappeared and nowadays there are attempts to bring back life-styles associated with traditional family farming as an instrument to prevent emigration and anchor population to rural areas.

While family farms now produce for markets many manifest serious ingrained problems. Small family farms, such as those of Feiraco cooperative, seem to have reached a balance between life-style, culture and market: excessive fragmentation of farms into plots despite much consolidation remains a negative factor. A restructured and consolidated family farm context large or productive enough to ensure economic viability, guarantee the quality of life, underwritten by inherited cultural practice and respect for environment is possible. It is necessary to get away from the kinds of academic inertia that still consider small farm complexes like (minifundismo) as an unchangeable element that cannot evolve or adapt in rural Galicia. Nowadays we have a different small farm complex connected with both commercial and polycultural family farming (Ferrás et al., 2004; Walshe, 2010). In the Irish case, family farming on holdings greater than fifty hectares of productive lands was neither able to preserve traditional culture nor inherited mixed farming and selfsufficiency. Family farming in Ireland experienced an unstoppable process of productive specialization until it became a model of industrial production.

\section{Methods}

This research consists of theoretical and empirical sections. The theoretical part focuses on the analysis of specialized bibliography on minifundismo and family farming. We try to present the theoretical background that allows us to provide new ideas about minifundismo and family farms. The empirical part focuses on examining different instances in Galicia and Ireland. In Galician, Feiraco cooperative and its hinterland was examined in the area of $\mathrm{Val}$ da Barcala near the emblematic city of Santiago de Compostela (fig. 1). This instance may be considered as a model of a small-holding cooperative complex in Galicia. In the Irish instance, where family farming is still present within an agricultural system modernized over the twentieth century, we focus on an analysis of Drinagh cooperative and its hinterland in West County Cork, extending to the boundary of 
County Kerry, where cultural landscapes show interesting similarities and contrasts with Val da Barcala (figure 2). Both areas are characterised by rough lowland and upland topography and many valleys linked to a dense network of rivers and streams, the presence of Atlantic "bocage" with enclosed fields, the presence of forested areas and the prevalence of meadows and pastureland (O'Flanagan, 1996; Ferrás, 1996).

The specific objectives pursued by the proposed research can be summarized in three points:

- Identifying recent social, economic and cultural changes experienced by the family farms in a globalizing world.

- Producing a positive definition of small farm complex (minifundio) revised in relation to family agriculture, pluriactivities and rural marketing.
- Making comparisons and contrasts between case studies in Galicia and County Cork, Ireland (Ferrás, 1996).

The scale of this study is defined by the hinterlands of Feiraco and Drinagh cooperative societies that respectively involve about 1500 dairy farms. The research process started with a questionnaire survey among the farmers involved in the study in Galicia and Cork Ireland (Ferrás et al., 2004 ${ }^{1}$ ). Direct contact with the small farmers enabled us to carry out a comparative study where the particular situation of a representative sample of the farming families was analysed. Key features helped us to learn about the daily activity in the family farms were examined. The aspects addressed related to technological qualification, farm structure, economy and productivity, life-style, work organization, wel-

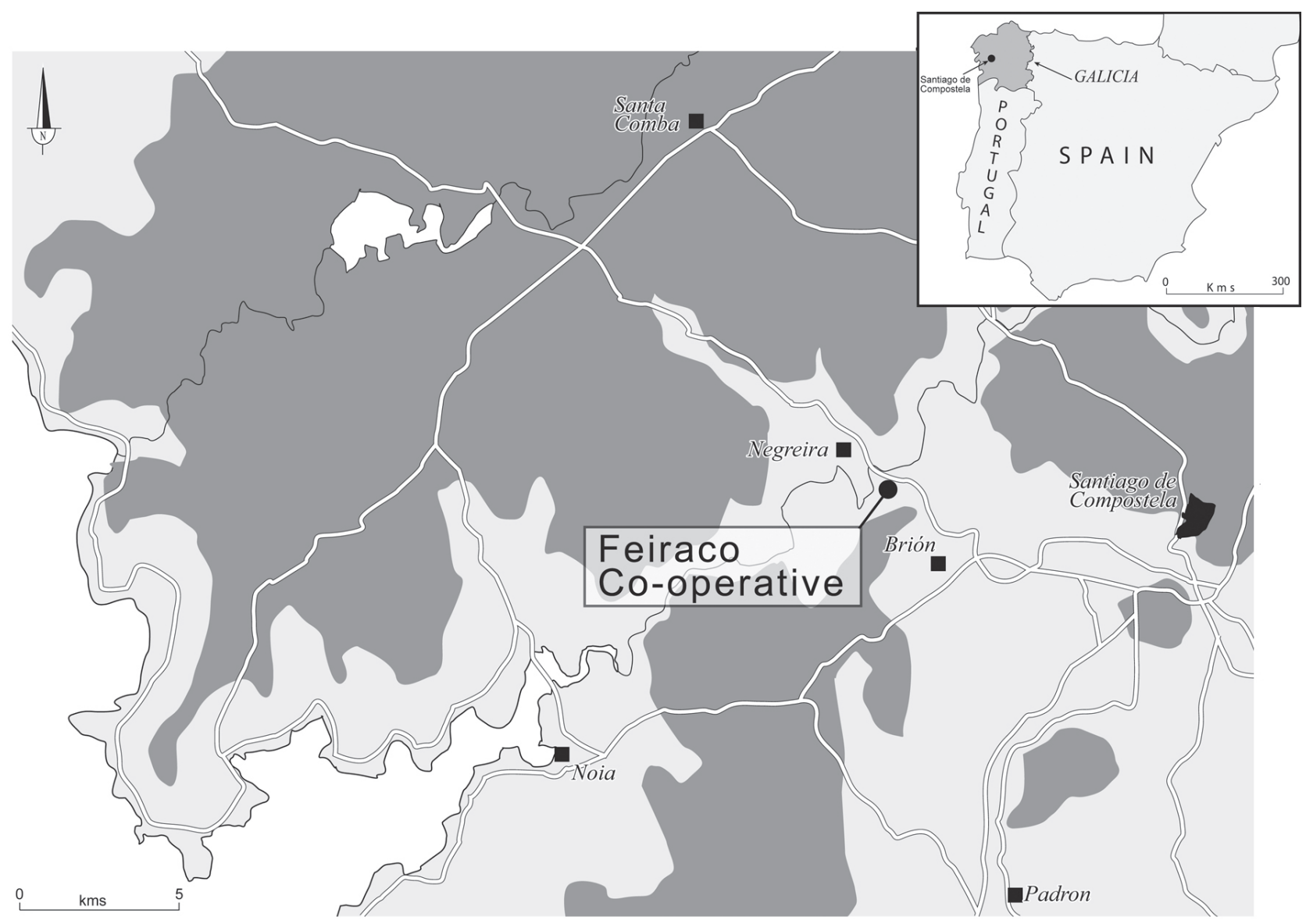

Figure 2: Location of Feiraco in Galicia (Spain) Localisation de Feiraco en Galice (Espagne)
1. Ferrás Sexto C., Armas Quintá F.X., Macía Arce C., García Vázouez Y., 2004. Un novo escenario para a economía galega. Minifundio sostible e agricultura familiar ecolóxica: análise de caso da cooperativa Feiraco. Communication in II Congreso de Economía de Galicia, Universidad de Santiago de Compostela. 
fare and housing, social reproduction, demography, future prospects for the families, mobility, emigration, assessments of agricultural and rural policies, social and community life, leisure and inheritance practices.

Our research objectives were to attempt to compare and contrast the characteristics and problems of family farms linked to Feiraco and Drinagh cooperatives. In the Galician case, fields work involved 325 family farms being visited in 27 different municipalities and 115 parishes covering Feiraco's hinterland corresponding to the western part of the province of Corunna. In the Irish case, 60 family farms distributed randomly in West Cork and South Kerry were surveyed. The questionnaire was administered in both cooperatives. Respondents were selected through a systematic-randomized statistical method exclusively amongst active cooperative members. The research involved a survey with 315 uestions addressed to the household heads interviewed on the farm, throughout several programmed visits in the spring-summer months of 2004. A team of four interviewers collected information over an accumulated period of eight months. Later on, a data base with 150000 entries was inputted and analysed through SPSS.

The information was used to profile Galician rural areas in comparison with the Irish ones in relation to their respective experience as working cooperatives. Rural Galicia, especially Feiraco's hinterland went through profound changes in the last three decades. Here, we refer to rural modernization and the transformation of subsistence agriculture into a commercial mode (Escuela de Enseñanza Social de Galicia, 1982; Besançon and Chevassus, 1984). Thousands of minute farms disappeared and those that remained expanded considerably ensuring improved economic welfare of the producer families (Liñares et Giraut, 1995). In the Irish case, in general, and in the case of Drinagh, in particular, the modernizing transformation towards a capitalist family farming goes back to the beginning of the twentieth century, when agricultural reforms initially implemented by the British became a reality in rural Ireland. Such transformation resulted in plot consolidation, settlement re-structuring and virtual disappearance of traditional farming culture, that is, of mixed farming and self-sufficiency (Boylan et al., 1991; Walsh, 2007; Aalen et al., 2011). In rural Ireland, out-migratory flows were constant and unusually large until practically 1970s and 1980s, when a remarkable return to the countryside started (Ferrás, 1996). These processes of social, economic and cultural transformation in Galician and Irish rural areas were influenced by regional, national and European policies, although with different timing and intensities. However, both in Galicia and in Ireland, the social and economic reality of rural areas is very different nowadays and, therefore, we think these two realities should be assessed rigorously within the context of the new European rural policies that strive to anchor population more firmly in the countryside, to end rural movement towards cities and to boost pluriactive productive complexes that affirm existing rural culture.

\section{MINIFUNDISMO AND FAMILY FARMING IN THE LITERATURE}

In Galicia, academic literature has historically presented minifundimo and its social and economic realities as a deficient family farming system suffering from very serious problems preventing agricultural modernization. Minifundios were considered as miniature farms, unable to secure the basic sustenance for all the members of the family unit and, ultimately, a source of many evils afflicting Galician society. Also, the demarcation of boundaries between plots was the cause of constant lawsuits, all too frequent in the rural areas in Galicia (Villares and López Andión, 1974; López Iglesias, 1996; and more recently, Varela Fraga, 2002²). Scholars involved in the study of the rural areas such as García Fernández (1975) stressed the social deprivation associated with minifundismo farming complexes, while other authors such as Bouhier (1979), Beiras (1981) and Fernández Prieto (1995) hinted at a positive interpretation that questioned an exclusive economic assessment of minifundismo. It did not and does not coincide with the goals of capitalist industrial agriculture. On the other hand, recent research carried out in the province of Corunna by López Garrido and al (2003) show, through a statistical-empirical analysis, that there are no significant

2. Varela Fraga, 2002. Reflexiones sobre la litigiosidad en el medio rural gallego, Comunicación presentada en la Jornada Autonómica de Galicia, Libro Blanco de Agricultura (www.libroblancoagricultura.com/libroblanco/ jautonomica/ galicia/comunicaciones/valera.pdf). 
differences between the technical efficiency in dairy farms in consolidated-plot areas and in non-consolidated ones. This opens a question mark about the socio-economic returns from expensive plot-consolidation policies. López Iglesias (1996), Sineiro and Valdês (2002) confirm the viability of a majority of dairy family farms in Galicia thanks to the availability of income from pensions. However, they do not quantify such income or comment on why it should contribute to economic stability. A causeeffect relationship cannot be established between pension volumes and the productive status of small family farms without considering culture, mentality and social traditions prevalent in the rural areas.

Abel Bouhier (1979), a French geographer, supported the need to gradually transform old rural structures in Galicia, bearing in mind the large variety of nuances of its geography. That is why, Bouhier never attempted to analyse plot consolidation studies of the "ancient Galician agricultural complex" - as he titled it. He never considered the impacts of urbanization or the development of industrialization on the countryside, all have been active processes greatly transforming the agricultural landscape in Galicia since the 1960s. Views about preservation and gradual transformation of Galician rural areas promoted by Bouhier in 1960s were never understood by government agencies. Nowadays, in the context of the Common Agricultural Policy, it has acquired great importance. An appreciation of rural heritage to initiate cultural/ green and rural tourism, support for organic agriculture and extensive farming and, finally, the promotion of the perception of the countryside as an ideal place to live and produce in an environmentally-friendly way stem directly from Bouhier's thinking.

In Ireland, agricultural modernization resulted in the disappearance of some traditional farming complexes. García Fernández (1976) and O’Flanagan (1996) argued, from a humanistic viewpoint, that family farming modernization, technical innovation and market orientation in the European Atlantic periphery resulted in massive emigration to cities. In Ireland, regrettably, inherited traditions and customs were lost and were replaced by a largely monofunctional, highly mechanised, specialising in milk production within a capitalist agricultural system.

Family farming can be considered a life-style adapted to a rural post-productive and pluriactive world which is beginning to lose its negative connotations. Producing more and cheaper, following the industrial capitalist logic is not the overriding concern any more for many rural communities; however, their aim is to produce sufficient and value added quality products. The new Common Agricultural Policy (2007-2013) promotes the consolidation of pluriactivity in rural spaces and activities helping the emergence of new employment opportunities for local communities. Organic farming has a good understanding of the labour-intensive character of minifundismo - an environmentally-friendly activity that is increasingly expanding its market share. Mixed farming is a traditional practice of sustainable agriculture supported by organic fertilizers, labour intensity and natural control of pests and parasites. On the other hand, counter-urbanization favours population increase in smaller towns and villages and the drying up of migratory flows from rural to urban areas. It creates functional, economic and cultural diversity that may result in opportunities in less-favoured rural areas (Ferrás, 2000³).

Local and/or endogenous development diversifies productive activities by promoting services such as green or rural tourism. Business co-operativism joins individual efforts of small farms in a profitable way and even hobby farming fits into the restructuring of post-productivist minifundios, as neither of them exclusively produce for the market. Rural family pluriactivity is envisaged as a chance to join different income sources and to enhance economic possibilities. In sum, the concept of the minifundio should be part of a new paradigm about the countryside and rural areas. That is, rural areas should be perceived not just as places to produce but also places to live in harmony with the environment. An understanding of minifundio in relation to sustainable family farming should be derived from a cultural point of view that complements the prevailing excessively economic conforming view. In international academic literature, there are approaches with a scientific-empirical background, that stress economic viability and the social and cultural assets invested in small properties. Toledo (1993) and Rosset (1990; 1998) advocate an environmentally-friendly cultural

3. Ferras Sexto C., 2000. Counterurbanization and Common Agricultural Policy. Implications for the Galician country. International Colloquium New Urban and New Rural Pattern, Asamblea Parlamentaria del Consejo de Europa, Strasbourg. 
relationship of human beings with the environment and question the need for a capitalist industrial agriculture to guarantee food security. Family farming should be assessed on pluralistic analytical views, as it cannot be simply synonymous with deficient agriculture from a purely economic viewpoint. Parttime agriculture cannot simply be attached with a pejorative meaning associated to its econ omic viability (Etxezarreta, 1985).

\section{FAMILY FARMING AND COOPERATIVISM: CASES ANALYSIS in Feiraco and Drinagh}

Feiraco cooperative was founded in 1969 near the town of Negreira, in the region of A Barcala, in Galicia. At present, about 7500 families are affiliates; some 1500 members are active dairy farmers and the rest are beneficiaries of different services, such us meat and feed marketing, retail sales, workshops and fuel supplies. As for Drinagh cooperative, like Feiraco, it acts as service corporations providing for local farming families. In total, there are 1500 members specialized in milk production also benefiting from certain services. Drinagh is a cooperative dating back to 1923 and it takes its name from the area where it was founded (figure 3). Unlike Feiraco, Drinagh does not market or process milk.
There is a quality brand called "Golden Vale" that refers to an extensive region of south west Munster. This "brand" or marketing label is supported by public administration and processes and markets the milk from many co-operatives - Drinagh among them. This place marketing practice has a strategic dimension. It allows for an efficient use of economic resources addressed to sales and promotion and, at the same time, it frees the individual cooperatives from those duties. Feiraco and Drinagh employ 150 staff each.

Feiraco and Drinagh cooperatives have given a boost to the farming evolution of thousands of rural families. These cooperatives replaced traditional self-sufficient farming economy by a market economy and formerly prevailing subsistence mixed farming by forage crops. In the Galician case, it did not simply compromise subsistence production thanks to seed selection and the improvement of farming systems. Feiraco and Drinagh could be considered examples of commercial viability, socially responsible community enterprises devoted to the promotion of rural development. The joint efforts of thousands of dairy farmers sustained cooperatives that nowadays are competing in local and foreign markets with multinational companies with large economic and technological resources, such as Nestlé, present both in Galicia and Ireland. Feiraco

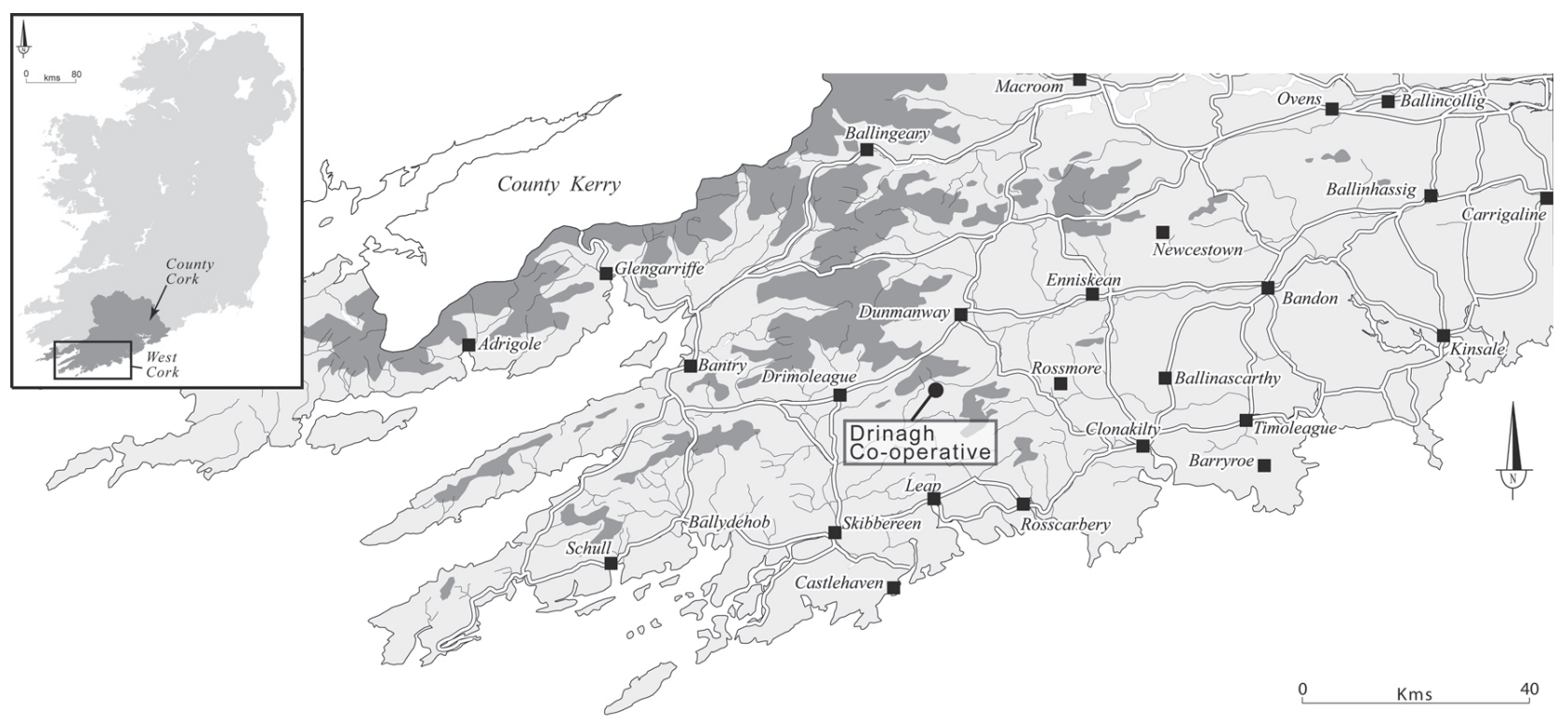

Figure 3: Location of Drinagh (Ireland)

Localisation de Drinagh (Irlande) 
and Drinagh, as agricultural cooperatives, provide rural families with various services promoting upskilling education and advice about how to channel their production to the market.

In the following pages we illustrate the results of the analysis of cases in Galicia and in Ireland: the demographic characteristics of the respondent families; their technological investments, their social and economic levels of satisfaction, their lifestyles, social reproduction and their evaluations of support policies.

The data show high levels of satisfaction and welfare of the respondent families both in Ireland and in Galicia. The fact that almost all the families believe that they enjoy a satisfactory life in the rural areas is remarkable (between 90 and 100 per cent). Also, most consider their economic situation good and perceive themselves as belonging to a middle social class (between 78 and 98 per cent). However, there are some problems evident especially perceived by young people. In Feiraco's case, these problems relate to ageing, conflict between generations, stagnation of the land market, poor qualifications, lack of interest by young people in the farm and excessive property divisions. In the Irish case of Drinagh, farming families show greater demographic and social vitality, however today they may be too specialized in milk production; they have a businessdirected approach to farming and they have adapted to variations of milk market prices. The social, economic and cultural profiles of the farms that belong to Feiraco and Drinagh cooperatives are presented below (tables 1-8).

\section{Population characteristics}

In the Galician case, unlike the Irish example, the social and demographic context reveals the importance of ageing and low education qualifications (table 1). At Feiraco, the population above sixty-five years accounts for twenty-three per cent as opposed to six per cent in Drinagh's case. The population above thirty with a university qualification is $2.7 \%$ in Drinagh as opposed to the negligible 0.1 per cent in Feiraco. In the Galician case, members of the cooperative are usually extended families and up to three core family generations can be found living in the same household - that is, three married couples from three different generations. Grandparents, parents and children with their respective spouses and descendants live together. This situation can have positive but also negative implications. From the economic point of view, stem family incidence strengthens purchasing power, as grandparents' and dependents' pensions provide households with substantial extra income, up to recently unknown in rural areas. Beside that, pensioners also participate in the work of the farm. In extended conversations held with the farm families, statements such as "grandparents can do nothing but work" and "if they stop working they will die" were frequent comments.

However, different generations' living together on the farm may have negative outcomes when there is a conflict between mentalities and educational backgrounds. Frequently, formally uneducated grandparents and parents often adopt attitudes of inertia and are systematically opposed to the innovative projects of the younger family members. Statements such as "It is enough for me" or "It is not worth it as I am not going to live for long" are frequent. A consequence of this conservative behaviour is the movement of young people towards wage-earning jobs outside the farm, mainly in a nearby town or city. It is worth stressing that unemployment rates are exceptionally low for cooperative members, especially in the Irish case (3.2 and 4.7\%). Regrettably, outward migration in both areas, especially in Ireland is on the rise again due to a massive fall of in local construction activities.

\section{Technological investment}

There is a clear contradiction in relation attitudes to investment; that is, preferences of the co-operative member families regarding farm investment. Feiraco's families, unlike Drinagh's, are involved often in excessively expensive machinery purchase which can only be employed episodically (table 2 ). Different households even compete for the most modern and powerful machines. However, there are few preferences and little interest in investing in professional technical qualifications (45 per cent in Drinagh and 35 per cent in Feiraco), nor in buying new land ( $8 \%$ in Drinagh and 26\% in Feiraco), although in the Galician case the prime reason is that the land market is stagnant (López Iglesias, 1996). The paradoxical situation is that there is an excess of machines and a lack of training, both basic 


\begin{tabular}{|c|c|c|}
\hline & DRINAGH & FEIRACO \\
\hline Number in each household & 4 & 5 \\
\hline$\%$ male $>65$ & 5.2 & 20.2 \\
\hline$\%$ female $>65$ & 7.5 & 26.5 \\
\hline Population $\%<5$ years & 6.5 & 3 \\
\hline$\%$ of population $>55$ years non qualified & 13.6 & 92 \\
\hline$\%$ of population with a university degree & 10 & 2 \\
\hline$\%$ of population $<30$ years with university degree & 7.5 & 1.3 \\
\hline$\%$ of population $>30$ with university degree & 2.7 & 0.1 \\
\hline Unemployment rate $(\%)$ & 3.2 & 4.7 \\
\hline Birth rate $(\%)$ & 12.6 & 4.2 \\
\hline
\end{tabular}

Table 1: Feiraco (Galicia) and Drinagh (Ireland): Demographic characteristics of families, 2004 (Source: Survey of dairy producer families, 2004 / enquêtes auprès des familles de producteurs laitiers, 2004)

Notes. Birth rate was estimated from the 0-4 age group (population 0-4 / $5 \times 1000 /$ total population). Unemployment rate is the quotient between unemployed population and active population in percentage (population $>16)$. Caractéristiques démographiques des familles enquêtées en 2004, Feiraco (Galice-Espagne) et Drinagh (Irlande)

\begin{tabular}{|c|c|c|}
\hline & DRINAGH & FEIRACO \\
\hline$\%$ of households purchasing machinery during the last 5 years & 43 & 100 \\
\hline$\%$ of households making a farm investment during the last 5 years & 100 & 94 \\
\hline$\%$ of households with investment in educational qualifications during the last 5 years & 45 & 35.3 \\
\hline$\%$ of families with investments in new land in the last 5 years & 8.3 & 26 \\
\hline
\end{tabular}

Table 2: Feiraco (Galicia) and Drinagh (Ireland): Technical qualification and investments, 2004 (Source. Surveys of dairy producer families, 2004 / enquêtes auprès des familles de producteurs laitiers, 2004)

Qualification technique et investissements, Feiraco (Galice) et Drinagh (Irlande), 2004

and technical. The land market in Ireland seems to be even less dynamic than in the case of Galicia.

\section{Farm characteristics: Socio-economic satisfaction}

Feiraco's family farms produce for selling and therefore are market-driven. Milk sales are the main source of income and meat to a much lesser extent. Mixed farming and self-sufficiency are still identity marks and even inherited cultural features. Maize-potato cultivation, vegetable growing and pig and poultry farming are driven by self-sufficiency and maintenance of dairy farms (tables 3 et 4). However this is now sustainable in relation to the profits it generates for household maintenance. An average size of 9.7 ha per farm confirms an important increase in relation to the recent past (Ferrás et al., 1995). Feiraco was a pioneer during 1950s in the plot consolidation process and now, a completely new plot consolidation strategy is required. A leading structural problem remains: excessive plot division, with an average of fourteen plots per farm. This makes modernization and efficient use of farm machinery difficult. However, a positive element is that plots are often located within a two-kilometre radius of the house, except in rare cases and always in the same townland.

The differences between Feiraco and Drinagh are really remarkable with respect to mixed farming. Irish farms do not produce maize, wheat or potatoes; they do not produce pigs or poultry, nor are they remarkable for forest ownership (12\% against 90 in the Galician case). Drinagh has an average of 58 cows per holding in contrast to 34 cows per farm in the case of Feiraco and they retain more than double the average milk production capacity of the Galician farms (193000 litres/year in contrast to 94000 litres/year). Also, Drinagh's farmers own an average of more than 38 ha of agricultural land per farm in contrast to 10 ha in the case of Feiraco and they have access to a much more dynamic rental land market (table 3). In sum, Feiraco and Drinagh are two different cooperative models; high produc- 


\begin{tabular}{|c|c|c|}
\hline & DRINAGH & FEIRACO \\
\hline Average number of cows per holding & 58 & 34 \\
\hline$\%$ of households growing maize and potatoes & 0 & 93 \\
\hline$\%$ of households rearing pigs & 0 & 93 \\
\hline$\%$ households rearing poultry & 0 & 98 \\
\hline Average size of farms (ha.) & 38.2 & 9.7 \\
\hline Average number of plots per farm holding & 5.9 & 14 \\
\hline $\begin{array}{l}\text { Average distance in kilometres } \\
\text { from plots to the farm centre }\end{array}$ & 4 & 2 \\
\hline Average number of ha. of woodland per holding & 1.2 & 5.5 \\
\hline$\%$ of households owning woodlands & 11.6 & 90 \\
\hline Average number of woodland plots per household & 4.2 & 13 \\
\hline $\begin{array}{l}\text { Average ha. of non-owned worked land } \\
\text { per household }\end{array}$ & 18.1 & 2 \\
\hline Average holding milk yield per year (litres) & 193.165 & 93.827 \\
\hline $\begin{array}{l}\text { Percentage of holdings } \\
\text { producing more than } 100000 \text { litres of milk a year }\end{array}$ & 55.2 & 32.4 \\
\hline
\end{tabular}

Table 3: Farm characteristics of Feiraco (Galicia) and Drinagh (Ireland), 2004 (Source. Surveys of dairy producer families, 2004 / enquêtes auprès des familles de producteurs laitiers, 2004) Caractéristiques des exploitations étudiées, Feiraco (Galice) et Drinagh (Irlande), 2004

tion specialization in the Irish case and a mixture of commercial agriculture with maintenance and practice of the traditional farming culture in the Galician case.

It is remarkable that the economy of the cooperative members has a clearly mixed or symbiotic character both in Feiraco as in Drinagh. In both cases the main income source is the sale of milk $(77 \%$ and $98 \%$ respectively); in the Galician case there is a high dependence on subsidies and pensions almost three out of four farms receive some type of pension $(20 \%$ in Drinagh and 68\% in Feiraco (table 4). Also, more than half of the family farms have members employed outside the farm in the Irish case (53 per cent in contrast to $20 \%$ in Feiraco). That income is complemented and supplemented, in the Galician case, with returns in kind arising from a still self-supporting family farming . Another important consideration is that there is almost no unemployment amongst the members of co-operative families; a situation which has recently changed for the worst (table 4).

\section{Life-style and Work organization}

Work organization on the farm suffers from serious imbalances between the genders (table 5). In the Galician case, data reflects a comfortable position for men, as half the adult male heads of the household also work outside the farm, while women - mothers and grandmothers - are in charge of a great part of farm activities, apart from looking after the children and the house $(97 \%$ in Feiraco in contrast to $67 \%$ in Drinagh). In the Galician case,

\begin{tabular}{|l|l|l|}
\cline { 2 - 3 } \multicolumn{1}{c|}{} & DRINAGH & FEIRACO \\
\hline Percentage of households whose main income source is the sale of milk & 98 & 77 \\
\hline Percentage of households with production above 30000 litres of milk per year & 78 & 80 \\
\hline Percentage of households with income from employment in industry or services & 53.3 & 20 \\
\hline Percentage of households with income from pensions or subsidies & 20 & 68 \\
\hline
\end{tabular}

Table 4 : Feiraco (Galicia) and Drinagh (Ireland): Income and Input (Source. Surveys of dairy producer families, 2004 / enquêtes auprès des familles de producteurs laitiers, 2004) Revenus des exploitants étudiés, Feiraco (Galice) et Drinagh (Irlande) 


\begin{tabular}{|c|c|c|}
\hline & DRINAGH & FEIRACO \\
\hline$\%$ of female household heads involving in farming & 58 & 96 \\
\hline$\%$ of women in the household unit working in the house and in charge of the children & 66.7 & 96.5 \\
\hline$\%$ of male heads of the household working outside the households farm & 5 & 50 \\
\hline$\%$ of children in the household unit working part-time on the farm & 45 & 46 \\
\hline
\end{tabular}

Table 5 : Life-style and work organization, Feiraco (Galicia) and Drinagh (Ireland) (Source. Surveys of dairy producer families, 2004 / enquêtes auprès des familles de producteurs laitiers, 2004)

Mode de vie et organisation du travail, Feiraco (Galice) et Drinagh (Irlande)

we can establish the frequency of situations when men displayed special interest in handling machinery, in contrast to women, who showed special concern for farm work and children. In relation to male work, it is worthwhile to stress the fact that male household heads generally work the farm in Drinagh (95\% of the total), while only half work on the farm in the Galician case; women being in charge of the animals, farm work, children and the elderly. We can state that in the Irish case, unlike the Galician one, there is greater professionalism and work differentiation according to gender participation on family farms, which are themselves more specialized in industrial milk production.

In both instances, children's participation in farm activities is almost marginal. Children are mostly occupied studying or working outside the farms. Only five per cent work full time on family farms and around $45 \%$ work part time, especially on weekends and/or sporadically in seasonal work such as in the excavation of slurry pits, cleaning and administration. There do not seem to be suitable channels to allow generation replacement nor to channel the working life of young people back to the family farms. This trend is more evident in Feiraco's case, where ageing is a serious hindrance to innovation on the farm. There, conservatism of the generation that owns the farms hinders most attempts to promote change; a fact mooted by younger family members. An immediate result of this conservatism is that many young people give up working in the farm and start their careers outside, mainly in the service and construction sectors.

Housing conditions are comfortable in both areas. Houses of family's members of Drinagh and Feiraco are large and spacious enough to lodge a family unit that normally comprises four or five members (an average of $212 \mathrm{~m}^{2}$ and $183 \mathrm{~m}^{2}$ respectively) (table 6). In both cases, refurbishing is common practice in traditional rural houses as is also the construction of new ones nearby, or else attached to older ones. House construction often has been financed by the savings of returned migrants. Almost all the houses count mains water connections, electricity supply and telephone (about 90-95\%). They are also provided with the essential domestic appliances. The presence of a computer is infrequent in the Galician case; they are evident only in nine per cent of households, in contrast to fifty-five per cent in the Irish case. This is a critical indicator of the dimensions of the technological gap in the rural areas in Galicia.

\section{Social reproduction and emigration}

Research confirms that both in Drinagh and in Feiraco, dairy farmers are happy to live in rural areas (between 90-100 per cent). They consider themselves as belonging to a middle class and perceive their economic situation as good (table 7). These are very positive indicators and assure the continued

\begin{tabular}{|c|c|c|}
\hline & DRINAGH & FEIRACO \\
\hline Average surface of house size $\left(\mathrm{m}^{2}\right)$ & 212 & 183 \\
\hline Average age of houses (years) & 40 & 50 \\
\hline$\%$ of houses with essential services (water, light, basic domestic appliances, telephone) & 95 & 90 \\
\hline$\%$ of houses with computer & 55 & 9 \\
\hline
\end{tabular}

Table 6: Feiraco (Galicia) and Drinagh (Ireland): Characteristics of the houses (Source. Surveys of dairy producer families, 2004 / enquêtes auprès des familles de producteurs laitiers, 2004)

Caractéristiques des maisons, Feiraco (Galice) et Drinagh (Irlande) 
social and economic viability of co-operative family farming. Emigration was at a standstill until recently and return migration was exceptional. Both Feiraco and Drinagh co-operatives and many rural areas in Galicia and Ireland overcame the traditional imbalances between available economic resources and a dependent demographic situation (Ferrás, 1996). In the case of Galicia, present problems are of an ageing rural population and cultural and generation gaps between poorly qualified adults and more educated young people. A passive attitude of the former offers resistance to change and hinders modernization and innovation often causing young people to flee. They are employed outside the farm, mainly in the nearby towns and cities; in contrast with the past, they do not emigrate; they commute every day or week and even every month between the work place and their rural home. Both in the Irish case and in the Galician one, young people prefer to earn less money being employed in construction or hotels and restaurants, rather than stay at home working exclusively on the family farm. As for the future expectations, favourable attitudes exist towards additional plot consolidation where it has been clearly insufficient as detected in the Galician case. There was a widespread shared opinion about the need to revise plot consolidation implemented since 1950s. A growing commercial vocation and concerns for the oscillations of milk prices; $53 \%$ and $67 \%$ in the Irish and Galician family farms respectively were also identified (table 7).

\section{Agricultural policies critique}

Co-operative families make a positive assessment of productivist agricultural policies. They appreciate plot consolidation, the milk-quota system and affo- restation supports. Remarks about the productionquota system being a guarantee for credit institutions were frequent.

Besides that, in Ireland family farms are of a more industrial type, larger and better capitalized than the Galician ones. On the other hand, a reduced appreciation of rural policies embodying employment diversification is evident at Feiraco. For instance, rural tourism was not appreciated and 56\% of farmers were not aware of its economic possibilities. Finally it is worth stressing the fact that policies to control forest fires are given a very positive assessment in Feiraco's family farms (in $97 \%$ of the farms), however, forest fires are not considered a problem in the Irish case (table 8).

\section{Social life and inheritance practices}

Social and community life was rated as being really very poor amongst Feiraco's co-operative families (3\% in contrast to $58 \%$ in the case of Drinagh) (table 9). Leisure activities at the weekend were scarce: family visits and religious attendance stand out. On the other hand, holidays were really exceptional in the Galician case (17\% in contrast to $57 \%$ in Drinagh farms). On Galician farms, remarks such as "animals eat everyday" and "animal do not take holidays" were frequent. A close emotional relationship has been established between the farm owners and the animals; the former believe they owe permanent attention to the latter. They have adopted attitudes of distrust and think nobody else can replace them in the management of the farm. We are undoubtedly witnessing cultural inertias inherited from traditional agricultural systems. The need to boost social and community life is very urgent as is promotion value systems prioritizing time off and leisure.

\begin{tabular}{|c|c|c|}
\hline & DRINAGH & FEIRACO \\
\hline$\%$ of households showing satisfaction living in a rural areas & 100 & 91 \\
\hline$\%$ of households who consider their economic position is good & 81,7 & 94 \\
\hline$\%$ of households who consider themselves middle social class & 78,3 & 97 \\
\hline$\%$ of households with emigrants & 8,3 & 2 \\
\hline$\%$ of households with returned emigrants & 11,7 & 2 \\
\hline Average number of children per family & 2,6 & 1,5 \\
\hline $\begin{array}{l}\% \text { of households who consider } \\
\text { low milk prices the main problem }\end{array}$ & 53,3 & 67 \\
\hline
\end{tabular}

Table 7: Feiraco (Galicia) and Drinagh (Ireland): Social reproduction, Future, Emigration (Source. Surveys of dairy producer families, 2004 / enquêtes auprès des familles de producteurs laitiers, 2004)

Reproduction sociale, avenir et émigration, Feiraco (Galice) et Drinagh (Irlande) 


\begin{tabular}{|c|c|c|}
\hline & DRINAGH & FEIRACO \\
\hline$\%$ of households who perceive the milk-quota system as positive & 90 & 99 \\
\hline$\%$ of households who positively perceive low interest-rate credit systems & 48 & 79 \\
\hline$\%$ of households who have a positive assessment of plot consolidation & 45 & 97 \\
\hline$\%$ of households who have a negative assessment of rural tourism promotion & 75 & 56 \\
\hline$\%$ of households who give a negative assessment of forest fires prevention and control & 45 & 3 \\
\hline
\end{tabular}

Table 8 : Feiraco (Galicia) and Drinagh (Ireland): Assessment of agricultural policies (Source. Surveys of dairy producer families, 2004 / enquêtes auprès des familles de producteurs laitiers, 2004) Évaluation des politiques agricoles, Feiraco (Galice) et Drinagh (Irlande)

In both cases - the Irish and the Galician one inheritance systems are perceived as a real problem. In $77 \%$ of the farms in Drinagh and in $97 \%$ of farms in Feiraco (table 9), families have not made up their minds about the inheritance procedures and sequence. The problem is especially serious in Galicia due to the higher degree of ageing within many family units. Information obtained relating to this item is confusing and contradictory and often camouflages the present situation. Most respondents preferred simply not to give opinions. Data show clearly the generation gap once again and, in the Galician case, this resistance to address reality results from the extended family living in the same farm and under the same roof. Individual aspirations relating to inheritance give rise to latent tensions in the families and on the farms and also to a deep crisis relating to traditional values.

\section{Conclusions}

Family farming in the case of Galicia, as an inherited cultural practice and "singular" life-style may become sustainable providing opportunities for the modernization of family farms. It is necessary to define a productivity threshold for sustainable minifundismo; a threshold that ensures an acceptable quality of life for rural families, preserves their life- style and inherited cultural practices linked to mixed farming and pluriactive economy. Minifundismo, understood as a family farming complex of small and medium owners, could be fostered as a life-style with its own characteristics that should be nurtured and supported against the cultural and economic uniformity of globalization. In Galicia mass withdrawal from farming is taking place amongst families not linked to cooperatives and out migration for many younger family members is gathering momentum. In Ireland farm size and farm type influences rates of non inheriting outmigration. Excellent prices for agricultural commodities of very recent times have restrained movement of other farms

In the Drinagh co-operative instance, we can verify how agricultural transformation and modernization gave a boost to a monocultural purely market-oriented family farming complex, specialized in milk production. Irish family farms have more cattle (in Drinagh 58 and in Feiraco 34) and large extensions of land are tilled for forage. Irish family farming today is industrial and capitalist in nature, producing for the market as a specialized economy. Nevertheless, it went through a period of severe crisis with the spread of the bovine spongiform encephalopathy and nowadays it is recuperating sustainable family farming practices that ensure viability in the context of the European Common

\begin{tabular}{|l|c|c|}
\cline { 2 - 3 } \multicolumn{1}{c|}{} & DRINAGH & FEIRACO \\
\hline$\%$ of households participating in local associations & 58,3 & 3 \\
\hline$\%$ of households that took holidays during the last year & 57 & 17 \\
\hline$\%$ of households that do not participate in leisure activities at the weekend & 5 & 7,7 \\
\hline$\%$ of households who have not made a decision about the inheritance system & 77 & 97 \\
\hline
\end{tabular}

Table 9: Feiraco (Galicia) and Drinagh (Ireland): Social life and inheritance system (Source. Surveys of dairy producer families, 2004 / enquêtes auprès des familles de producteurs laitiers, 2004)

Vie sociale et système d'héritage, Feiraco (Galice) et Drinagh (Irlande) 
Agriculture Policy, which aims to achieve sustainable rural development.

Sustainable minifundismo and cooperative family farming herald a new scenario for the Galician rural economy in the context of the new European Common Agricultural Policy and globalization. Traditional self-sufficient minifundismo does not exist in Galicia any longer; however many of its cultural legacies must be considered worthwhile economic practices that may adapt to the present conditions having very positive attitudes such as respect for animals, natural cattle feeding and mixed farming practices. The Irish case shows clearly the dangers of specialization in family farming, envisaged exclusively as a milk producing company, and although it is true that it promotes productivity and efficiency, it is also true that the local rural biodiversity and cultural diversity disappear. We argue that the concept of minifundismo must be reformulated. Our research regards the existence of minifundsmio in relation to pluriactive family farming as an economically-viable and ecologically-sustainable family farming complex, as long as modernization and the up-skilling of cooperative family farms is achieved. For those reasons it is necessary to reflect critically about the characteristics and social, economic and cultural profiles of small family farms in the context of rural development policies.

In the Galician case, ageing amongst the milkproducing farming families, as a result of a very low birth rate, entails serious problems for future viability of productive activities. In the Irish case, demographic vitality is a really positive factor that induces innovation and social dynamism in rural areas. In contrast to Feiraco, Drinagh co-operative families participate actively in social activities, enjoy their leisure time and annual holidays, have computers at home and now have greater access to higher qualification and training. The generation gap in the Galician family farms is a reality derived from the survival of the extended stem family within the rural household, something that has been replaced in the Irish rural world. Even so, younger people, with a higher educational level, leave the farm for employment. There are cultural resistances by older adults due to habits and life-styles inherited from the past. In the case of Galician farms, the effective absence of leisure time causes rejection of farming as a career and life-style among younger people. In the Galician rural world, excessive holding divisions illustrates the need for carrying out a new plot consolidation so as to offer new incentives for further commercialisation. In the Irish case, plot consolidation was carried out at the beginning of the twentieth century synchronized with a settlement planning scheme. It is worth stressing women's excessive work load in Galicia: women undertake work in the farm, look after house and family. Meanwhile and unlike the Irish instance, men are employed outside the family farm or work as self-employed. Women's social and labour market position are more precarious. They are in almost in a fixed cultural context of traditional gender roles, with inertias from the past remaining very difficult to modify.

Nonetheless, positive attitudes are evident in the Galician as in the Irish case involving aspects that strengthen the viability of family farming and social and economic development in the rural areas. Unemployment was low in the early 2000 s amongst the member families of the Feiraco and Drinagh cooperatives (values are around four per cent of the total active population): this situation has now radically changed. Co-operative members consider their socio-economic position as being buoyant and most of them express satisfaction living in a rural area (between 90 and 100 per cent of respondents). Emigration from Ireland is growing: in Galicia it remains at a standstill as people do not wish to move. Besides, a good communications network with frequent and fast transport allows daily commuting to study, work, shopping or business. All these characteristics are very different from the 1960's and 1970's and should make us reflect about the meaning of an emerging rural world.

Rural off-farm pluriactivities promoted by the European Common Agricultural Policy fit well in the traditional system of polyculture still vibrant in Galicia. In Ireland and amongst members of Drinagh, off-farm pluriactitivies are critical as a stabilising element for at least half of the cooperative members (Walshe, 2010). Farming families have enough inter-generational human resources available to start out new productive activities in rural areas; however they require specific training, advice and incentives. Promotion of entrepreneurship among young people becomes strategic for the future local economic development and for cooperative success. Besides, green, environmentally- 
friendly farming corresponds with traditional family farming practised historically and has cultural principles and values that favour human-nature equilibrium. The treatment received by animals is in tune with the respect they deserve as living creatures is completely opposed to the industrial approach that considers them as mere productive elements of the capitalist agriculture.

In short, the experience of Feiraco and Drinagh as co-operative societies of milk-producing farms is a reality. They constitute a business model of co-operative agriculture of small and medium farmers that captures great social, economic and cultural value for an emerging rural world. They show that the joint effort of all small and medium farmers' families can prove profitable and underwrite ecologically and culturally sustainable futures. Opinions about the small-farm complex [minifundismo] in Galicia must be revised given social and business experiences such as Feiraco and Drinagh's in Ireland. At present, the sustainability of a family farming complex of rural land owners should be envisaged as a life-style with its own cultural characteristics that should be respected and assessed positively, in opposition to the blinkered way of thinking promoted by globalization. Comparative research on Feiraco and Drinagh confirms that cooperative family farming ensures the economic viability of rural areas, slows down emigration from rural to urban areas and strengthens farmers' traditional relationship with their environment.

\section{Acknowledgements}

We thank Mr Joe O'Sullivan, Manager, Drinagh Cooperative County Cork and its Board of Management for permission to conduct interviews with their members; the former President of Feiraco Mr. Jesús García Calvo for permission to conduct to interviews with members of Feiraco and for a generous financial contribution; Mr Michael Murphy and Mr. Jesús Vázquez, Cartographers, Geography Department, University College Cork and Gist. Idega, University of Santiago de Compostela, for the preparation of figures 1 and 3; Elaine Cullinane, M.Phil. and Georgina Ferris, M.Phil. for conducting the interviews in Ireland and Yolanda García, M.Phil. and Mariña Pose, M.Phil. for carrying out the interviews in Spain and inputting the data. Also thanks are due to M. J. Marin Fuertes for translation. We would also like to thank two anonymous referees fro their helpful comments. Any remaining errors are the author's responsibility.

\section{Bibliography}

Aalen, F., Whelan, K., Stout, M. (2011). Atlas of the Irish rural landscape, $2^{\mathrm{d}}$ edition, Cork University Press, Cork, $432 \mathrm{p}$.

Alvarez Rodríguez J.A., Liñares Giraut X.A., López Cachaza M.L., 1987. Feiraco: una cooperativa agraria gallega ante la Comunidad Económica Europea, Facultad de Geografía e Historia, Universidad de Santiago, 220 p.

Beiras Torrado X. M., 1981. O atraso económico de Galicia, Galaxia, Vigo, 209 p.

Bounier A., 1979. La Galice. Essai géographique d'analyse et interprétation d'un vieux complexe agrarie, Thèse d'État de l'Université de Poitiers 1977, 2 tomes, Édition de l'Imprimerie Yonnaise, La Roche-sur-Yon, 1516 p.

Besançon S., Chevassus, E., 1984. Quel avenir pour le minifundisme galicien? : les exploitations laitieres de la Comarca de Negreira face à l'entrée de L'Espagne dans la CEE, INAPG, ENSAM, 240 p.

Boylan T.A., Varley T., Cuddy M.P., 1991. Rural crisis: perspectives in Irish Rural Development, Centre for Development Studies, University College Galway, 244 p.

Crecente Maseda R., Álvarez López C., 2000. Una revisión de la concentración parcelaria en Europa, Estudios Agrosociales y Pesqueros, no. 187, p. 221-274.

Conoley C., Walsh J., Menedith, D., 2008. Irish farming at the millennium. A Census Atlas, Dublin, 430 p.

Covas Riveiro C., 1989. Origen y evolución de una cooperativa de campo: Feiraco, Santiago de Compostela, 230 p.

Escuela de enseñanza social de Galicia, 1982. Evolución socio-económica y cambio social en la comarca de A Barcala, Documento fotocopiado, Santiago de Compostela, 210 p.

Evans N., Morris C., Winter M., 2002. Conceptualizing agriculture: a critique of post-productivism as the new orthodoxy, Progress in Human Geography, no. 26/3, p. 313-332.

Etxezarreta M., (dir.), 1985. La Agricultura insuficiente: la agricultura a tiempo parcial en España, Instituto de Estudios Agrarios, Pesqueros y Alimentarios. Madrid, 442 p.

Evans E., 1958. The Atlantic Ends of Europe, Advancement of Science, vol. 15, p. 54-64

Fernández Prieto L., 1995. O dominio da explotación agraria familiar na Galicia contemporánea, dans LiñARES X. A. (ed.), Feiraco e o Val de Barcala, Feiraco S. Coop. Lmta, Santiago de Compostela, p. 143-149.

Ferrás Sexto C., 1996. Cambio rural na Europa atlántica. Os casos de Galicia e Irlanda 1970-1990, Xunta de Galicia and Universidade de Santiago, Santiago de Compostela, 431 p.

Ferrás Sexto C., Macía Arce X.C., García Vázquez, Y., Armas Quintá, F.X., 2004b. O minifundio sostible como un novo escenario para a economía galega, Revista Galega de Economía, vol. 13, no. 1-2/2004, p. 73-96. 
García Fernández J., 1975. Organización del espacio y economía rural en la España atlántica, Siglo XXI, Madrid, 332 p.

García Pascual F., (coord.), 2001. El mundo rural en la era de la globalización: incertidumbres y potencialidades, Ministerio de Agricultura, Pesca y Alimentación, Universidad de Lleida, Madrid, 524 p.

IDEGA, 2001. Conclusiones IV Coloquio Hispano Portugués de Estudios Rurales, Universidad de Santiago, Santiago de Compostela. [www.usc.esłidega].

Liñares Giraut A. (ed.), 1995. Feiraco Vintecinco Anos. Un modelo de agroindustria cooperativa. Tomos I, Santiago de Compostela, 235 p.

López ANDión X. M., 1992. Estructura agraria y economía rural en la Galicia interior. La Tierra Chá y el centro de la Meseta lucense, Thèse de Doctorat, Universidad de Santiago, 630 p.

López Iglesias, E., 1996. Movilidad de la tierra y dinámica de las estructuras agrarias en Galicia, Ministerio de Agricultura, Pesca y Alimentación, Madrid, 533 p.

López Iglesias, E., Sineiro García, F., Valdés Pazos, B., 2002. Relación entre las características familiares y productivas de las explotaciones de bovino gallegas, Seminario de la Asociación Española de Economía Agraria "El sector lácteo español”, www.usc.es/idega/reseminario.html].

O’Flanagan P., 1996. Xeografía histórica de Galicia, Xerais, Vigo, 220 p.

Pose Antelo X.M., 1995. Os primeiros cen anos de cooperativismo europeo: significación histórica, política, económica e social, dans X.A. Liñares Giraut (ed.), Feiraco e o Val da Barcala. Un camiño de progreso, Feiraco S. Coop. Lmta., Santiago de Compostela, p. 36-40.
Presidencia del Senado, 2000. Informe de la Comisión Especial para el Estudio de los Problemas del Medio Rural, Estudios Agrosociales y Pesqueros, no. 187, p. 277-332.

Ribas A., Flores G., López Garrido C., 2003. A eficiencia técnica das explotacións leiteiras na comarca interior da provincia de A Coruña. Influencia da concentración parcelaria, IDEGA, Santiago de Compostela, Documentos de Traballo no. 16, 53 p.

Rosset P., Carrol, c., vandermeer, j., 1990. Agroecology, McGraw-Hill, New York, 641 p.

Rosset P., Lappe F.M., Collins J., 1998. World Hunger, Grove Press, New York, 275 p.

SNeddon Ch. S., 2000. Sustainability in ecological economics, ecology and livelihoods: a review, Progress in Human Geography, no. 24/4, p. 521-549.

Toledo V., 1993. La racionalidad ecológica de la producción campesina, in E. Sevilla, M. González (eds.): Ecología, campesinado e historia, Ediciones la Piqueta, Madrid, p. 197-218.

Villares Paz R. E., López Andión X. M., 1974. Minifundio, Gran Enciclopedia Gallega, Gijón, 340 p.

Villares Paz R., 1996. Figuras da Nación, Xerais, Vigo, 287 p.

Walsh J. A., 2007. Agriculture in transition: the experience of Ireland, in B. Bartley and R. Kitchen (eds), Understanding Contemporary Ireland, Pluto Press, London, p. 158-169.

Walshe, N. 2010. Pluriactivity and the Irish Family Farm. The Blackwater Region, 2001-2006, Doc Diss. National University of Ireland, Cork, (non publié). 